The disturbed area on the sun was situated near the south pole in the eastern quadrant. Two photographs of this region were secured, one at $3 \mathrm{~h}$. $14 \mathrm{~m}$. p.m., G.M.T., and the other at 3 h. 5om. p.m., G.M.T. In the first (see Fig. I) the arches are clearly visible and complete, but in the second they are less discernible and partially broken up, in spite of the fact that the second photograph had the better exposure.

The tnost conspicuous feature of the whole disturbed area, shown in Fig. I, is the series of three concentric arches, which nearly reach down to the chromosphere. Their heights, as measured from the chromosphere, are $I^{\prime} 5,2^{\prime} 9$, and $3^{\prime} 6$. The radii of the arches photographed and measured by Prof. Dyson for the I90I eclipse were $1^{\prime \cdot 2}, 2^{\prime} 4$, and $3^{\prime \cdot} 7$. It will thus be seen that both are of about the same order of magnitude.

It will be noticed further that the intensity of the arches is not uniform; thus the outside one has five points of increased intensity, while the next in order has three such maximum points. On the eastern side of these arches there is another distinct semioval whieh intersects two of the three main arches. On the southern side are some minor projections from the chromosphere which by their curvature seem to indicate that they form part of the whole disturbance.

The magnitude of this very active region will be

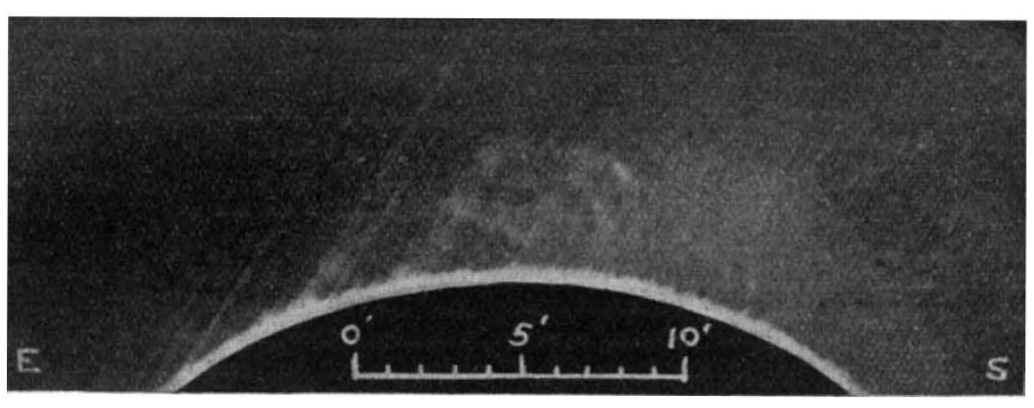

FIG. I.-A prominence in the form of " arches" photographed in " $\mathrm{K}$ " light on July 17, 1907, at the Solar Physics Observatory, South Kensington.

more readily grasped when it is stated that the extreme portions were separated by $\mathrm{I2}^{\prime \cdot 7}$ and the highest point from the chromosphere measured $3^{\prime \prime} 6$. Thus the breadth extended 353,000 miles, or more than three-quarters of a solar radius, and the height was about ror, 600 miles.

It is interesting to note that there is apparently no large prominence underlying these envelopes, but whether there is one just on the near or far side of the limb cannot be stated.

The above photograph demonstrates that "arches", similar in form and magnitude to those secured during eclipses have now been photographed in the light of calcium vapour. This indicates that at any rate one of the components of the material of which they are built up is calcium. As the spectrum of the corona has no line at this wave-length, the deduction may be made that the arches photographed during eclipses are most probably of "prominence" and not of " coronal" material.

We have, therefore, another link in the chain to show the dependence of the form of the corona on prominence activity.

Since the above paper was communicated to the Royal Society, M. A. Hansky has published the results of his discussion of the corona pictures he secured at the total solar eclipse of August, 1905, and one of the conclusions which he has arrived at is as follows :-

" Il est très probable que la forme et la direction des rayons coronaux dépendent de la form et la direction des protubérances au-dessus desquelles ils se trouvent" (Mitt. d. Nikolai-Hauptsternwarte zu Pulkowa, Band ii., 1907, No. I9, p. I18).

William J. S. Lockyer.

\section{DR. A. W. HOWITT, C.M.G.}

BY the death of Dr. A. W. Howitt, recorded in NATURE of March 12 (p. 443), a link has snapped between the old days of the perilous exploration of Australia and the detailed scientific investigations of the present day. As early as 1858 , Mr. Howitt's knowledge of bush-craft was such that a syndicate in Melbourne appointed him head of an expedition to acquire a tract of the "Promised Land" in Central Australia, of the existence of which Warburton had recently confirmed the report of Stuart. In I86o he conducted a prospecting expedition in Gippsland. The following year he was selected to lead a party in search of the ill-fated Burke and Wills Expedition, of which John King, the last survivor, was rescued; later Mr. Howitt penetrated into the Great Stony Desert. Thus for many years Mr. Howitt had a wide personal acquaintance with the physical characters of southern and south-eastern Australia. On his numerous expeditions and journeys he came into close and friendly contact with the natives, some of whom were in a condition of complete savagery, and, later on, circumstances enabled him to acquire considerable influence over tribes in south-east Australia, so much so that he was even permitted to be present at their sacred ceremonies.

In $1873, \mathrm{Mr}$. Howitt joined the late Dr. Lorimer Fison in investigating the classificatory system of relationship which obtains among certain tribes, as well as the tribal class system and the rules of marriage and descent connected therewith. These investigations were published in 1880 in their memorable book, "Kamilaroi and Kurnai," which laid the foundations of a truer conception of Australian scciology than was previously possible. Of similar joint authorship were papers " From Mother-right to Father-right" and "On the Dene and the Horde," in the Journal of the Anthropological Institute ( 8882 , 1884). In the same journal, from 1883 to I908, Mr. Howitt published a series of papers of great value dealing with Australian sociology, initiation ceremonies, religion, and other phases of native customs and beliefs. In the production of these Mr. Howitt was assisted by some sixty correspondents from various parts of the continent; these informants were subjected to continued questioning, which elicited more detailed knowledge. Mr. Howitt also published in the annual report of the Australasian Association for the Advancement of Science (I890, I89I, I90I), papers "On the Use of Gesture Language in Australian Tribes," "Anthropology in Australia," and "On Trade Centres in Australian Tribes." On the occasion of the meeting of the British Association in Cambridge in 1904, the University of Cambridge presented Mr. Howitt with the honorary degree of Doctor in Science, in recognition of his ethnological investiga-

No. 2005 , vOL. 77] 
tions. Later in the same year Dr. Howitt published, with Messrs. Macmillan and Co., Ltd., his great work on "The Native Tribes of South-east Australia," in which is embodied his life's work in ethnology. By far the greater part of the materials was collected and recorded before i 889 . Since then the native tribes have more or less died out, and in the older settlements of south-eastern Australia the tribal remnants have now almost lost the knowledge of the beliefs and customs of their fathers. Fortunately, Dr. Howitt began to observe and collect information before it was too late, but even then much had disappeared.

Dr. Howitt's book contains a great mass of information concerning numerous tribes, and thus it serves as an invaluable storehouse for students, but it is more than this, as it embodies the mature opinions of the father of Australian ethnology, who, by his kindly and sympathetic nature, was able to gain and retain the confidence of his native friends. The opinion of a man of such prolonged and varied experience in the field, combined with the knowledge of what others had collected, must always carry weight. The collecting and recording of complete ethnological data are naturally matters of first impcrtance, but of even greater interest is the true appreciation of the ideas which underlie the actions of men. He who has lived among the people he describes should be the best interpreter of their ideas and ideals, and in these matters we are not likely to find a surer guide than the genial explorer and student whose death will be deplored by ethnologists all the world over.

A: C. HadDon.

\section{NOTES.}

THE astronomical section of the Paris Academy of Sciences has elected M. Maurice Hamy, of the Paris Observatory, to succeed the late Dr. Janssen as a member of that section of the academy. M. Hamy entered the observatory in 1884 , and was awarded the Lalande prize in 1895 .

THE Paris correspondent of the Times states that the Academy of Sciences has appointed a committee, composed of MM. Becquerel, Bouquet de la Grye, and Poincare, to consider a suggestion by $\mathrm{M}$. Bouquet de la Grye concerning the application of wireless telegraphy to the problem of the determination of longitude at sea. The idea is to utilise the wireless telegraphy station of the Eiffel Tower in order to send, for instance, every night at midnight a Hertzian signal giving the time of the meridian of Paris. M. Bouquet de la Grye thinks, indeed, that if a wireless telegraphy station were established at the Peak of Teneriffe signals could be detected completely around the earth.

The next International Congress of Archæology will be held at Cairo in rgog.

Fon the purpose of discussing subjects of interest to those concerned in the work of museums, art galleries, and kindred institutions, a conference of members of the Museums Association and others interested will be held in the Harris Free Public Library and Museum, Preston, on the afternoon of Saturday, April r r.

THE twenty-fourth annual meeting of the Society of Dyers and Colourists will be held on April 3, at 4.30 p.m., at the Technical College, Bradford. The president, Prof. R. Meldola, F.R.S., will deliver his presidential address on "The Founding of the Coal-tar Colour Industry." The first awards of the Perkin medal will be made to Profs.

$$
\text { No. } 2005 \text {, VOL. 77] }
$$

C. Graebe and C. Liebermann for their synthesis of alizarin. On the evening of the same day the members of the society will dine together at the Great Northern Victoria Hotel, Bradford.

Earthouake shocks occurred at Mexico City during the evening of March 26, and were felt also at Guanajuata and Rincon. The town of Chilapa, in the State of Guerrero, was destroyed. The disturbances were recorded by Prof. Milne, F.R.S., at Shide, in the Isle of Wight; by Prof. Belar at Laibach, Austria; and by Prof. Michie Smith in southern India, all of whom communicated their observations to the Daily Mail. The earthquake is reported to have begun soon after iI p.m. on March 26, to have reached its maximum at 11.53 p.m., and continued for more than three hours. The shock was felt at St. Thomas, in the West Indies.

We learn from the April number of Nature Notes, the magazine of the Selborne Society, that at last a Bill is to be introduced into Parliament to restrict the importation of birds' skins, and so prevent in some measure the rapid extermination of beautiful birds, of which the egret (" osprey") and birds-of-paradise are typical examples. A short time ago, Lord Avebury, president of the Selborne Society, called together a meeting of representatives of the various learned societies at his house to consider whether legislation ought to be attempted, and this being the general opinion of those present, the main features of a Bill drafted by $\mathrm{Mr}$. James Buckland were adopted for presentation to the societies interested.

EFForTs are being made to form an Institute of Metals, which it is hoped by the promoters will follow similar lines to the Iron and Steel Institute. The proposed institute is intended to advance the knowledge of non-ferrous metals and their alloys, more especially copper, zinc, tin, aluminium, lead, nickel, silver, and platinum; to form a means of communication between members of the same trade; and to arrange periodical meetings for the purpose of discussing practical and scientific subjects relating to the metallurgy and use of the metals enumerated. A preliminary meeting was held in Manchester on March II, and was well attended. A representative committee comprising practical men engaged in the industries concerned and men of science was elected, and it was decided to arrange a further meeting in London. This special meeting will, we are informed, be held on June 10 next, at 2.30 p.m., at the Institution of Mechanical Engineers, Westminster. On this occasion the committee will report progress, and it is hoped the proposed institute will be constituted formally. All inquiries should be addressed to Mr. William H. Johnson, c/o Messrs. R. Johnson, Clapham and Morris, Ltd., 24 and 26 Lever Street, Manchester, who is acting for the honorary secretary, Prof. Carpenter, during his indisposition.

In the March issue of the Bulletin of the St. Petersburg Academy, Dr. E. Jäderholm gives a preliminary account of the hydroid polyps collected in the Arctic Ocean north of Siberia by the Russian Polar Expedition of 1900-3, while Dr. Salensky continues his description of the development of the gephyrean worm (mis-called echinoderm on p. 493 of our last issue) Echiurus.

THE American white ant (Termes flavipes) and the bagworm (Thyridopteryx ephemeraeformis) constitute, respectively, the subjects of two illustrated "Circulars," Nos. 50 and 97 , of the U.S. Bureau of Entomology. An excellent account is given in the first of these of the social economy 